日作紀（Jpn. J. Crop Sci.）85（3）：274-281（2016）

\title{
15 年間継続した水稲有機栽培の生育，収量および食味值
}

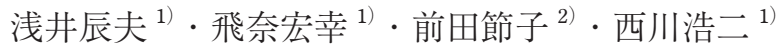 \\ (1) 静岡大学農学部附属地域フィールド科学教育研究センター, ${ }^{2}$ 静岡英和学院大学短期大学部)
}

\begin{abstract}
要旨: 静岡大学農学部附属地域フィールド科学教育研究センターの水田に掞いて, 堆肥を連用した水稲の有機栽培試 験を早生品種を用いて 15 年間継続して実施した。試験区として, 基肥に籾殼堆肥と菜種油粕を用い, 農薬を使用し ない籾殼堆肥区（1996２010 年）および基肥に牛糞堆肥を用い，農薬を使用しない牛糞堆肥区（1996２010 年）の 2 種類の有機栽培と, 基肥に化学肥料と農薬を使用する化学肥料区（1996２010 年）および基肥無しで農薬を使用す る無肥料区（1998～2010 年）を設定した。堆肥を連用する牛糞堆肥区で 5 年目以降，籾殼堆肥区で 6 年目以降に堆 肥の連用効果が認められた. 2006 2010 年の 5 年間の平均収量は, 籾殼堆肥区 $437 \mathrm{~g} \mathrm{~m}^{-2}$, 牛糞堆肥区 $430 \mathrm{~g} \mathrm{~m}^{-2}$, 化 学肥料区 $523 \mathrm{~g} \mathrm{~m}^{-2}$ および無肥料区 $329 \mathrm{~g} \mathrm{~m}^{-2}$ であった。食味分析計で測定した食味值は, 籾殼堆肥や牛糞堆肥を施用 する有機栽培が，化学肥料を施用する化学肥料栽培より高い傾向にあることが確認された。また，連用水田の土壤分 析から，堆肥連用の有機栽培区は，化学肥料区と比べて全窒素量が増加することが確かめられた.
\end{abstract} キーワード：牛䨢堆肥， 15 年間連用，食味，水稲，土壤分析，無肥料栽培，籾殼堆肥，連用効果.

食の安全や環境保全の観点から, 化学肥料や農薬に頼ら ない低投入・持続型水稲栽培が望まれている。化学肥料の 代替には緑肥や堆肥を連用し，農薬は使用しない有機栽培 を進展させねばならないが, 有機栽培は, 手間が掛かる割 には収量が低く，農家は経済的に苦しいことから期待に反 して拡大しないのが現状である。また，有機栽培に関する 試験は, 短期間で結論を見出し難く, 長期に渡る研究を必 要とするため報告例は少ない. 前田（2001）は, 除草剂使 用を前提とし，殺菌剂，殺虫剤をできる限り使わない低農 薬条件を考え，堆肥を連用した水田において，水稲コシヒ カリの収量性がどのように推移するかを 10 年間の継続試 験で検討した。齊藤ら（2001）は，実際栽培の視点から， 水稲の有機栽培に関する技術上の問題点を摘出・整理し て，新しい栽培方法を組み立てるための基礎的資料を得る ことを目的として，10 年間有機栽培を継続した。本試験 では，低投入・環境保全型の有機栽培を確立するために， 試験開始の前年までは化学肥料栽培を行っていた水田に㧈 いて，一定量の有機物を 15 年間連用により，生育特性， 諸形質, 収量性, 食味について比較検討した。

\section{材料と方法}

\section{1. 試験区と栽培方法}

試験は, 静岡県藤枝市の静岡大学農学部附属地域フィー ルド科学教育研究センター持続型農業生態系部門（北緯 $34^{\circ} 54^{\prime}$ ，東経 $138^{\circ} 16^{\prime}$ ，海抜 $13 \mathrm{~m} ）$ のグライ土の水田で行っ た. 水田は, 長辺が $70 \mathrm{~m}$, 短辺が $13.7 \mathrm{~m}$ の約 $10 \mathrm{a}$ で 1 筆 1 試験区で行った，試験区として，2 種類の有機栽培，す なわち籾殼堆肥区および牛顀堆肥区と比較対照としての化 学肥料区を設けた。そして， 3 年目の 1998 年から収量ポテ ンシャルを知る目的で無肥料区を追加した。
籾殼堆肥区では, 岡田（1953）が提唱した自然農法の実 践農家中嶋恒雄氏（静岡県御前崎市在住）の栽培法に従い, 中嶋氏が製造した籾殼堆肥と菜種油粕を連用した。籾殼堆 肥は, 籾款, 豚粪, 米糠, 発酵剂（エオコミット）を使い, 切り返しを繰り返しながら 8 ケ月積んだもので, 中嶋氏は 自然農法国際研究開発センターで認証を受けている。 5 月 下旬に $10 \mathrm{a}$ 当たり $400 \mathrm{~kg}$ の籾殼堆肥と $80 \mathrm{~kg}$ の菜種油粕を 投入するのを標準としたが，年次によって多少の増減があ り，2001 年には菜種油粕を施用しなかった(第 1 表). 1998 年に籾殼堆肥の全窒素の測定を行った，籾殼堆肥は あらかじめ $70^{\circ} \mathrm{C}$ の乾燥機で 1 日乾燥させた後, 粉砕器で 粉砕し, 分析した。分析は, $0.1 \mathrm{~g}$ のサンプルを KJEL TABS（分解促進剤）とともにケルダールチューブにいれ, 濃硫酸を $5 \mathrm{ml}$ ずつ加えて振とう後, 分解装置 $\left(420^{\circ} \mathrm{C}\right)$ で 3 時間分解させ, 20 分冷却させた後に蒸留水を $10 \mathrm{ml}$ ずつ 加えた。これをアクタックの KJELTEC AUTO SAMPLER SYSTEM 1035 ANARAIZER で測定した，籾殼堆肥の全窒素 含量 $2.55 \%$ を基に, 籾殼堆肥区の 15 年間の総窒素量を計 算すると, 籾殼堆肥の 15 年間の合計投入量は $6,300 \mathrm{~kg}$ で あり, 窒素量は $75.6 \mathrm{~kg}$ となる。これに菜種粕（窒素含量 5\%）の合計投入量 $1,155 \mathrm{~kg}$ からの $57.8 \mathrm{~kg}$ を加えると投 入した総窒素量は $133.4 \mathrm{~kg}$ となった。 標準的な年当たり の投入窒素量は, 籾殼堆肥から $5 \mathrm{~g} \mathrm{~m}^{-2}$ と菜種油粕から $4 \mathrm{~g}$ $\mathrm{m}^{-2}$ の合計 $9 \mathrm{~g} \mathrm{~m}^{-2}$ に相当した. 籾款堆肥は, 移植 $1 \sim 2$ 週 間前に散布し，その後耕耘した。牛䔬堆肥区は，試験開始 から 5 年間は, 当センター産の牛糞堆肥を使用したが, 2001 年以降は購入した完熟牛糞堆肥を $10 \mathrm{a}$ 当たり $450 \mathrm{~kg}$ 前後連用した。 また, 2002 年は牛䨢堆肥の代わりに緑肥 レンゲを, 2003 年は牛䨢堆肥と緑肥レンゲの両方を用いた。 牛糞堆肥の全窒素含量 $2.71 \%$ を基に, 牛糞堆肥区の 15 年

2016 年 2 月 2 日受理。連絡責任者：浅井辰夫 $\bar{\top} 426-0001$ 静岡県藤枝市仮宿 63

TEL 054-641-9500, FAX 054-644-4641, atasai@ipc.shizuoka.ac.jp 
第 1 表 年次別の有機物および化学肥料の施用量.

\begin{tabular}{|c|c|c|c|c|c|c|}
\hline \multirow[b]{2}{*}{ 年次 } & \multicolumn{2}{|c|}{ 籾殼堆肥区 } & \multicolumn{2}{|c|}{ 牛粪堆肥区 } & \multicolumn{2}{|c|}{ 化学肥料区 } \\
\hline & $\begin{array}{c}\text { 籵殼堆肥 } \\
\left(\mathrm{g} \mathrm{m}^{-2}\right)\end{array}$ & $\begin{array}{l}\text { 菜種粕 } \\
\left(\mathrm{g} \mathrm{m}^{-2}\right)\end{array}$ & $\begin{array}{c}\text { 牛糞堆肥 } \\
\left(\mathrm{g} \mathrm{m}^{-2}\right)\end{array}$ & $\begin{array}{l}\text { 菜種粕 } \\
\left(\mathrm{g} \mathrm{m}^{-2}\right)\end{array}$ & $\begin{array}{c}\text { 基肥 } \\
\left(\mathrm{g} \mathrm{m}^{-2}\right)\end{array}$ & $\begin{array}{c}\text { 穂肥 } \\
\left(\mathrm{g} \mathrm{m}^{-2}\right)\end{array}$ \\
\hline 1996 & 400 & 100 & 1200 & 0 & 5.0 & 3.0 \\
\hline 1997 & 400 & 80 & 780 & 100 & 5.0 & 3.0 \\
\hline 1998 & 400 & 100 & 1200 & 100 & 5.0 & 3.0 \\
\hline 1999 & 400 & 80 & 900 & 0 & 5.0 & 3.0 \\
\hline 2000 & 400 & 80 & 1000 & 0 & 5.0 & 3.0 \\
\hline 2001 & 400 & 0 & 420 & 0 & 5.0 & 3.0 \\
\hline 2002 & 400 & 75 & 0 & 0 & 5.0 & 3.0 \\
\hline 2003 & 500 & 80 & 450 & 0 & 4.0 & 3.0 \\
\hline 2004 & 450 & 80 & 450 & 0 & 4.0 & 3.0 \\
\hline 2005 & 600 & 80 & 1050 & 0 & 4.0 & 3.0 \\
\hline 2006 & 600 & 80 & 750 & 0 & 4.0 & 3.0 \\
\hline 2007 & 0 & 80 & 900 & 0 & 4.0 & 3.0 \\
\hline 2008 & 450 & 80 & 800 & 0 & 4.0 & 3.0 \\
\hline 2009 & 450 & 80 & 800 & 0 & 4.0 & 3.0 \\
\hline 2010 & 450 & 80 & 800 & 0 & 4.0 & 3.0 \\
\hline 合計 & 6300 & 1155 & 11500 & 200 & 67.0 & 45.0 \\
\hline
\end{tabular}

化学肥料区は, 窒素成分量を示す.

間の総窒素量を計算すると, 牛糞堆肥の合計投入量は $11,500 \mathrm{~kg}$ であり, 窒素量は $130.9 \mathrm{~kg}$ となる。これに菜種 粕の合計投入量 $200 \mathrm{~kg}$ からの $10 \mathrm{~kg}$ を加えると総窒素量は $140.9 \mathrm{~kg}$ となった。牛糞堆肥の年当たりの平均投入窒素量 は， $8.7 \mathrm{~g} \mathrm{~m}^{-2}$ に相当した，牛貨堆肥は，籾殼堆肥区と同様 に，移植 1 2 週間前に散布し，その後耕耘したが，1998 年は移植 3 ヶ月前, 1999 年は移植 4 ヶ月前および 2000 年 は移植 1 ケ月前に散布し，その後耕耘した． 5 月下旬の入 水後, 砕土と代掻きを行い, 6 月初めに播種後 21 日苗を 乗用型田植機によって条間 $30 \mathrm{~cm} \times$ 株間 $16 \mathrm{~cm}$ で移植した。 品種は，早生の ‘ひとめぼれ’を用いた。栽培に際しては, 農薬を一切使用しなかった。杂隹草対策として移植後 $2 \sim 3$ 週に機械除草を行い, 残った草は中干しまでに手取りで除 去し, 取り損なったヒエは種子を落とさないように収穫前 に抜き取った。中干しは，例年 7 月 10 日頃から 20 日頃ま で約 10 日間行った.

化学肥料区は，2 月下旬に土潩改良材のケイカルを $160 \mathrm{~g}$ $\mathrm{m}^{-2}$ 施用して耕耘し， 5 月中旬に再度耕耘した。 5 月下旬に 基肥として化学肥料を窒素，リン酸，カリの成分量でそれ ぞれ 4 5，5〜7，4〜8 $\mathrm{g} \mathrm{m}^{-2}$ を全層施肥した，その後移植 作業を行った。中後に穂肥として, 化成肥料を窒素, リン酸, カリの成分量でそれぞれ $3,1.3,3.9 \mathrm{~g} \mathrm{~m}^{-2}$ 表面 施用した。 15 年間の総窒素量は, 基肥の $67 \mathrm{~kg}$ と穂肥の 45 $\mathrm{kg}$ の合計 $112 \mathrm{~kg}$ であった，雑草対策として移植後 7 日前 後に除草剤（ダブルスター）を散布した。病害虫の防除は, 移植前にニカメイチュウを対象とした箱施用薬（プリンス 粒剂), 最高分けつ期頃にニカメイチュウとイネットムシ
防除の粒剤（パダン粒剂）および 8 月下旬に秋ウンカ，イ モチ病, 紋枯病防除のために水溶液散布（トレボン乳剂, カスラブサイドブル, モンカットフロアブル）を合計 3 回, 年次によっては 4 回行った.

無肥料区は, 化学肥料や有機物を全く使用しなかったが, 農薬は化学肥料区と同様に使用した。

\section{2. 生育および収量調査}

生育調查は, 移植後 3 週目から 9 週目まで 1 週間毎に, 各試験区の対角線の片方の等分点 3 箇所において, 各々連 続する 10 株, 計 30 株の草丈, 分けつ数, 葉色を測定した. 葉色は, ミノル夕製の葉緑素計 SPAD-502 を用いて展開完 了最上位葉の葉身中央部を測定し, SPAD 值で表した。

成熟期の 9 月下旬に生育調查をした 3 箇所を含む水田の 対角線の等分点 5 箇所において, 各箇所 10 株の稈長, 穂長, 穂数を測定した，収量調査の株は，調査した 10 株を地際か ら刈り取り,ビニールハウス内で 2 週間程架干し乾燥した後, 脱穀を木屋製作所の採種用脱穀機を用いて, 籾摺りを大屋 丹蔵製作所の坪㺫り試験用籾摺機を用いて行った。部分刚 り収量算出のため, 刚り取り箇所の栽植密度を調査した。 精玄米は, $1.80 \mathrm{~mm}$ 目櫛の回転式米選機（ダイワニューグ レイダーRICE UP R-15 型）を使用して調製した，精玄米 千粒重は, 精玄米 $20.0 \mathrm{~g}$ の粒数を計測し, 算出した。収量 $\left(\mathrm{g} \mathrm{m}^{-2}\right)$ は, 各箇所の株当たり精玄米重量と栽植密度との積 から算出した，収量調査で得られた平均值の区間差異の有 意性について分散分析と Tukey 法を用いて評価した。 


\section{3. 食味分析}

食味分析には, 収量調查で用いた精玄米を供試した。 1996 年〜2005 年は静岡製機の食味分析計（GS-2000）を用 いて分析した，この食味分析計は，1検体の分析に必要な 玄米量が $300 \mathrm{~g}$ 以上のため, 各試験区の調查地点 5 力所か らそれぞれ $300 \mathrm{~g} ， 5$ 検体を分析に用いた，2006 年〜2010 年はサ夕ケの米粒食味計（RCTA11A）を用いて分析した. この米粒食味計は, 1 検体 $500 \mathrm{~g}$ 以上のため, 各試験区の 調查地点 5 力所からそれぞれ $100 \mathrm{~g}$ を抽出し混合して $500 \mathrm{~g}$, 1 検体として分析に用いた，何れの食味計も，水分，タン パク質，アミロース，脂肪酸度打よび食味值を表示するが, 本報告では，タンパク質，アミロースおよび食味值のデー 夕を解析対象とした。

\section{4. 土袞分析}

各試験区水田から 2006 年 2 月 15 日（11 年目), 2010 年 5 月 22 日 ( 15 年目), 2013 年 2 月 25 日（18 年目）に土壤 を採取して分析した。すなわち，対角線採土法により，各 試験区水田の 5 箇所を選び, 表面の有機物を除き, 作土（表 土およそ0〜15 cm）をスコップで穴を掘り，斜め柱状に採 取した５箇所から採取した土壤を混合して 1 つにし，陰 干しした，白乾するまで十分に乾かした土塊を細かく砕き， 直径 $2 \mathrm{~mm}$ の篩を通し,篩別した土壤 $500 \mathrm{~g}$ を分析に供した。 分析は，十勝農業協同組合連合会へ依頼し，同農産化学研 究所が, 北海道立中央農業試験場・北海道農政部農業改良 課（1992）の土壤および作物栄養の診断基準－分析法（改 訂版) -に則って行った。

\section{結果と考察}

\section{1. 生育特性}

1996 年から 2010 年までの 15 年間の調査デー夕を用い て，生育特性を明らかにすることを試みた。

第 1 図に草丈の推移を示した。化学肥料区がすべての週 に扔いて最も長く，無肥料区が最も短く推移した，有機栽 培の籾殼堆肥区および牛粪堆肥区は，化学肥料区と無肥料 区の中間を同様の值で推移した。これら 2 つのは，化学 肥料区と比べて移植後 $4 \sim 5$ 週までは大きく劣ったが，移 植後 7 週目以降はその差が小さくなった.

第 2 図に $\mathrm{m}^{2}$ 当たり茎数の推移を示した. $\mathrm{m}^{2}$ 当たり茎数 も草丈と同様な傾向を示したが，草丈と異なるのは，籾款 堆肥区と牛糞堆肥区の間に差が見られ，籾殼堆肥区が牛糞 堆肥区より多かった，最高分けつ期は，化学肥料区が移植 後 5 週目で, 他の 4 区は 1 週遅れの移植後 6 週目であった. 移植後 5 週目まで化学肥料区と他の 4 区との差は大きかっ たが, 移植後 6 週目以降化学肥料区は急激に減少して籾殼 堆肥区に近づいた。籾殼堆肥区と牛粪堆肥区は，移植後 5 週目までは同様な推移を辿ったが, 移植後 6 週目以降には, 牛䨢堆肥区は籾殼堆肥区と比べて大きく減少した。

第 3 図に葉色の推移を示した。葉色を示す SPAD 值は,

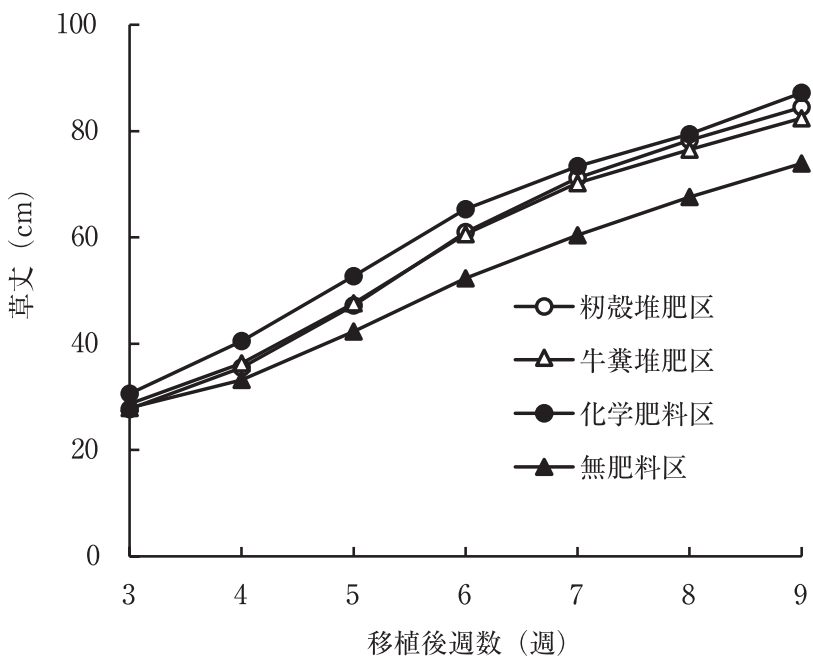

第 1 図 水稲草丈の推移.

$1996 \sim 2010$ 年の平均.

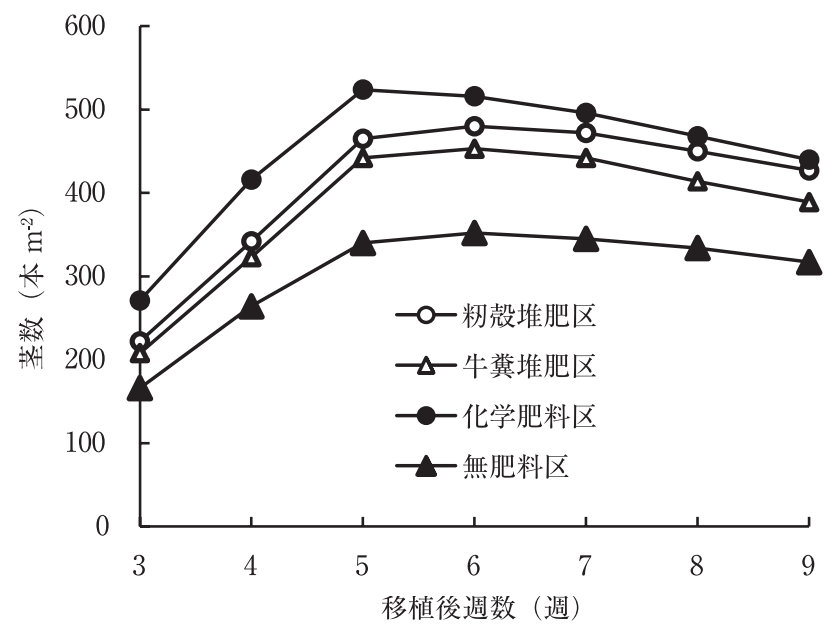

第 2 図水稲茎数の推移.

$1996 \sim 2010$ 年の平均

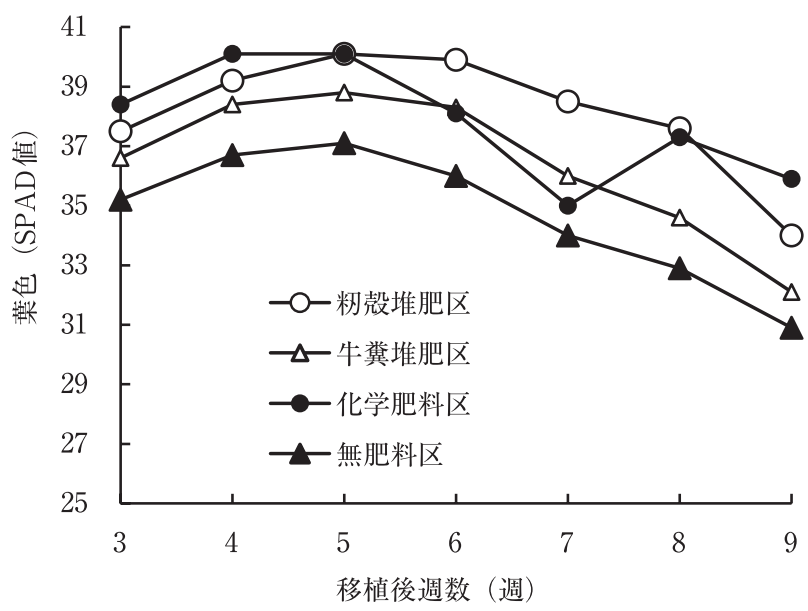

第 3 図水稲葉色の推移.

$1996 \sim 2010$ 年の平均. 
第 2 表 水稲における成熟期の諸形質（1996２010 年の 15 年間).

\begin{tabular}{cccccc}
\hline 処理 & 稈長 $(\mathrm{cm})$ & 穂長 $(\mathrm{cm})$ & $\mathrm{m}^{2}$ 当たり穂数 $($ 本 $)$ & もみわら比 & 精玄米千粒重 $(\mathrm{g})$ \\
\hline 籾款堆肥区 & $76.5 \pm 3.8^{\mathrm{b}}$ & $18.6 \pm 0.7^{\mathrm{b}}$ & $363 \pm 24^{\mathrm{ab}}$ & $0.93 \pm 0.08$ & $20.9 \pm 0.7^{\mathrm{b}}$ \\
牛粪堆肥区 & $75.0 \pm 4.7^{\mathrm{b}}$ & $18.5 \pm 0.4^{\mathrm{b}}$ & $335 \pm 41^{\mathrm{b}}$ & $0.92 \pm 0.10$ & $21.3 \pm 0.7^{\mathrm{b}}$ \\
化学肥料区 & $82.7 \pm 4.8^{\mathrm{a}}$ & $19.6 \pm 0.8^{\mathrm{a}}$ & $382 \pm 25^{\mathrm{a}}$ & $1.00 \pm 0.08$ & $22.2 \pm 0.7^{\mathrm{a}}$ \\
無肥料区 & $68.2 \pm 4.3^{\mathrm{c}}$ & $18.2 \pm 0.4^{\mathrm{b}}$ & $289 \pm 36^{\mathrm{c}}$ & $0.94 \pm 0.07$ & $21.6 \pm 0.7 \mathrm{ab}$ \\
\hline
\end{tabular}

異なるアルファベット間では，Tukey 法により $5 \%$ 水準で有意差があることを示す

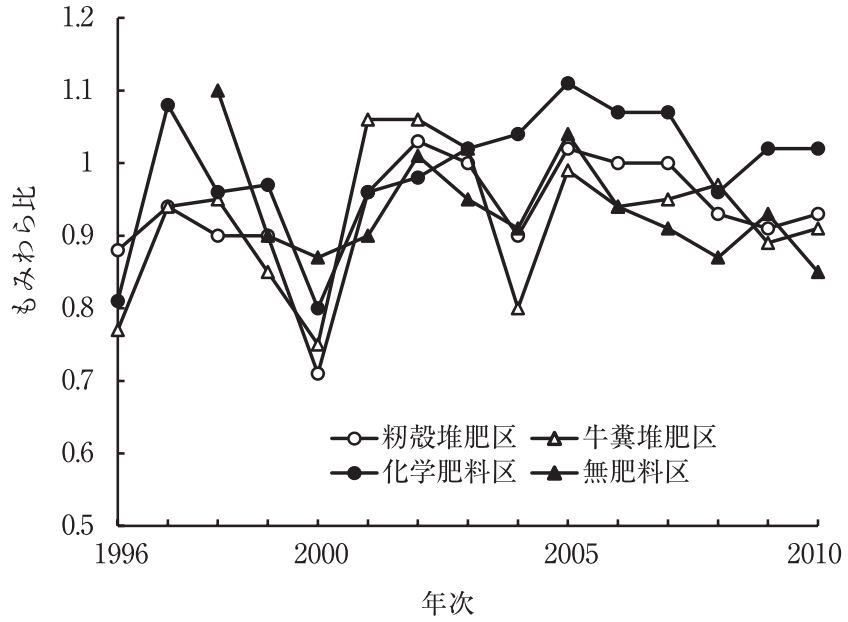

第 4 図 年次別もみわら比の変遷.

化学肥料区，無肥料区および有機栽培区でその推移を異に した。すなわち，化学肥料区は，移植後 5 週目まで何れの 区よりも最も高い值で推移し, その後急激に減少し, 穂肥 施用後の 8 週目に再び上昇して 9 週目には減少した。無肥 料区は, 終始低い值で推移して, 移植後 5 週目に最大值と なり，その後漸減した。籾殼堆肥区，牛粪堆肥区は，移植 後 5 週目に最大值となり, その後漸減した.

有機農法では慣行農法に比較して初期生育が劣ることが 多く指摘されている（上村ら 1983，片野 1990，鈴木ら 1994，酒井・山本 1999，玉置ら 1999，前田 2001，玉置ら 2002, 浅井ら 2013). 本研究の生育調查の結果からも, 何 れの有機栽培も, 慣行栽培と比べて初期の草丈, 茎数が明 らかに劣った。 しかし, 生育中期以降に急速に増大し, 生 育後期には, 草丈, 荎数ともに慣行農法に近づいた。

\section{2. 成熟期の諸特性}

第 2 表に 1996 年から 2010 年までの 15 年間の主要形質 の平均值を示した。程長は, 1997 年と 2002 年を除けば化 学肥料区が高く, 無肥料区が低く推移した. 程長は, 化学 肥料区 $82.7 \pm 4.8 \mathrm{~cm}$ >籾殼堆肥区 $76.5 \pm 3.8 \mathrm{~cm}>$ 牛 資堆肥区 $75.0 \pm 4.7 \mathrm{~cm}>$ 無肥料区 $68.2 \pm 4.3 \mathrm{~cm}$ の順 であった. 2 つ有機栽培は $76 \mathrm{~cm}$ 前後で類似していた。 穂長は, 化学肥料区が他の 3 区より有意に長く, 籾殼堆肥 区と牛糞堆肥区はほぼ同じであり，無肥料区は有機栽培区 と比べてやや短かった $\mathrm{m}^{2}$ 当たり穂数は, 化学肥料区が

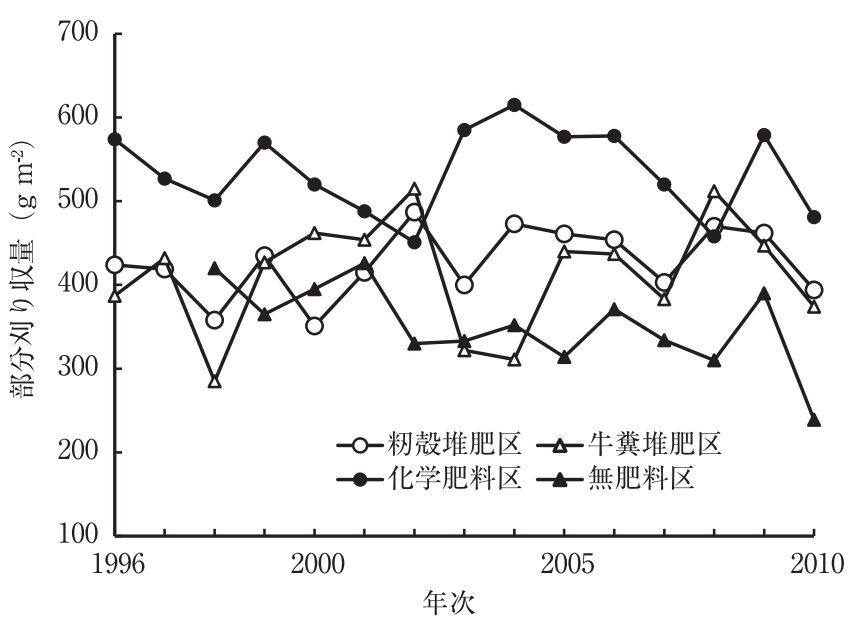

第 5 図 年次別水稲収量の変遷.

有意に多くて $382 \pm 25$ 本であった，有機栽培区では，籾殼 堆肥区が化学肥料区に次いで多く, 牛䨢堆肥区は, 籾殼堆 肥区より少なく, 無肥料区は化学肥料区より $23 \%$ 少なかっ た。もみわら比は，処理区間に有意差は認められなかった が, 化学肥料区が最も高く, 無肥料区, 籾喨堆肥区, 牛粪 堆肥区の順であった。片野 (1990), 齊藤ら (2001), 玉置 ら（2002）は，有機農法区では，もみわら比が高いことを 指摘しているが, 本研究では何れの有機栽培区も化学肥料 栽培区より低かった (第 4 図). 同じ有機栽培でも, レン ゲを用いる緑肥区（浅井ら，2013）は，堆肥を用いる籾殼 堆肥区や牛䨢堆肥区より高かった。精玄米千粒重は, 化学 肥料区が最も重く, 次いで無肥料区であった，有機栽培区 の牛粪堆肥区と籾殼堆肥区は, 化学肥料区と比べて有意に 軽かった。

上村ら（1983）は，化学肥料にきゅう肥をプラスするこ とにより穂数は増加し，千粒重，登熟歩合は低下したと報 告し, 神谷ら（1994）は，稲わら堆肥 $2 \mathrm{t} 10 \mathrm{a}^{-1}$ 施用の 12 年間の成績において, 有機物の施用により穂数, 一穂当た りもみ数は増加したが, 登熟歩合, 千粒重の低下がみられ たと報告している. 本研究は, 上村ら (1983)や神谷ら (1994) に比べたら低投入な有機栽培であるが, 穂数の増加は見ら れず，千粒重は軽かった。このことが, 収量が低い要因と 推察された。 
第 3 表 各農法区の部分刈り水稲収量の比較.

\begin{tabular}{|c|c|c|c|c|c|}
\hline 期 & 間 & $\begin{array}{c}\text { 籾殼堆肥区 } \\
\left(\mathrm{g} \mathrm{m}^{-2}\right)\end{array}$ & $\begin{array}{c}\text { 牛糞堆肥区 } \\
\left(\mathrm{g} \mathrm{m}^{-2}\right)\end{array}$ & $\begin{array}{c}\text { 化学肥料区 } \\
\left(\mathrm{g} \mathrm{m}^{-2}\right)\end{array}$ & $\begin{array}{c}\text { 無肥料区 } \\
\left(\mathrm{g} \mathrm{m}^{-2}\right)\end{array}$ \\
\hline $1996 \sim 2000$ 年 & (前 5 年間) & $397 \pm 35^{b}$ & $427 \pm 27 \mathrm{~b}$ & $538 \pm 29^{\mathrm{a}}$ & $393 \pm 22^{b}$ \\
\hline $2001 \sim 2005$ 年 & (中 5 年間) & $447 \pm 34 \mathrm{~b}$ & $470 \pm 33^{a b}$ & $543 \pm 63^{\mathrm{a}}$ & $351 \pm 39^{c}$ \\
\hline $2006 \sim 2010$ 年 & (後 5 年間) & $437 \pm 32^{\mathrm{a}}$ & $430 \pm 50^{a}$ & $523 \pm 49^{\mathrm{a}}$ & $329 \pm 53 b$ \\
\hline
\end{tabular}

平均 標準偏差. 無肥料区は, 1998 年からの 13 年間の平均を示す.

牛䨢堆肥区は, 1998 年, 2003 年および 2004 年を除いた平均を示す.

同行の異なるアルファベット間では，Tukey 法により $5 \%$ 水準で有意差があることを示す．

第 4 表 コメのタンパク質含有率の推移.

\begin{tabular}{|c|c|c|c|c|c|c|}
\hline 期 & 間 & $\begin{array}{c}\text { 籾殼堆肥区 } \\
\text { (\%, d.b.) }\end{array}$ & $\begin{array}{c}\text { 牛糞堆肥区 } \\
\text { (\%, d.b.) }\end{array}$ & $\begin{array}{c}\text { 化学肥料区 } \\
\text { (\%, d.b.) }\end{array}$ & $\begin{array}{l}\text { 無肥料区 } \\
\text { (\%, d.b.) }\end{array}$ & \\
\hline $1996 \sim 2000$ 年 & (前 5 年間) & $7.4 \pm 0.7$ & $7.2 \pm 0.5$ & $8.1 \pm 0.5$ & $7.0 \pm 0.3$ & n.s \\
\hline $2001 \sim 2005$ 年 & (中 5 年間) & $7.1 \pm 0.1$ & $7.1 \pm 0.5$ & $7.7 \pm 0.4$ & $7.0 \pm 0.4$ & n.s \\
\hline $2006 \sim 2010$ 年 & (後 5 年間) & $7.8 \pm 0.6$ & $7.6 \pm 0.6$ & $8.0 \pm 0.5$ & $7.7 \pm 0.8$ & n.s \\
\hline
\end{tabular}

平均 \pm 標準偏差. 無肥料区は, 1998 年からの 13 年間の平均を示す.

\%, d.b.は乾物でのコメのタンパク質の占める割合を示す.

n.s. は有意差がないことを示す.

\section{3. 部分刚り収量}

第 5 図に $\mathrm{m}^{2}$ 当たり部分刈り収量の変遷を示した。最も 収量が高かったのは化学肥料区で，451〜 $615 \mathrm{~g} \mathrm{~m}^{-2}$ の間を 推移し, 平均収量は $535 \pm 50 \mathrm{~g} \mathrm{~m}^{-2}$ であった。 最も収量が 低かったのは無肥料区で, $239 \sim 420 \mathrm{~g} \mathrm{~m}^{-2}$ の間を推移し, 平均収量は $352 \pm 49 \mathrm{~g} \mathrm{~m}^{-2}$ であった。 2 種類の有機栽培は, 籾款堆肥区が, 化学肥料区と無肥料区の中間の $351 \sim 487 \mathrm{~g}$ $\mathrm{m}^{-2}$ の間を推移し, 有機栽培に転換して 7 年目以降 $(2002$ 年), 収量の差が縮小した。平均収量は $427 \pm 40 \mathrm{~g} \mathrm{~m}^{-2}$ で, 化学肥料区との比率は $80 \%$ であった。牛粪堆肥区は, 285 $\sim 515 \mathrm{~g} \mathrm{~m}^{-2}$ の間を推移し, 有機栽培に転換して 5 年目以降 (2000 年), 収量の差が縮小した。平均収量が $413 \pm 66 \mathrm{~g}$ $\mathrm{m}^{-2}$ で化学肥料区との比率は $77 \%$ と低かった，牛䨢堆肥区 が低かった理由として，1998 年はウンカによる被害，2003 年, 2004 年は雑草のコナギの大発生による肥料養分の競合 による被害を受けて大きく減収した，本研究で設けた 2 種 類の有機栽培区では, 農薬や化学肥料を使用しなかったが, 農薬や化学肥料を使用する化学肥料栽培の $80 \%$ 前後の収 量を達成することができた。しかし，農薬を使用しないこ とから，年次によっては突発的な害虫や雑草の異常発生に より，無肥料栽培の収量を下回る事例も見られた。

\section{4. 堆肥の連用効果}

有機物の連用効果を検証するために, 15 年間を前 5 年間, 中 5 年間および後 5 年間に分け, それぞれの平均収量を比 較した (第 3 表)。牛糞堆肥区は, 無農薬による特異な影 響がない年次のデータをもとに連用効果を評価するため に, 害虫や雑草の異常繁殖に伴う負の影響が顕著であった 1998 年, 2003 年および 2004 年のデータは除いて解析した.
有機栽培区は, 籾殼堆肥区が前期 $<$ 後期 中期, 牛䨢堆肥 区が前期 $<$ 後期 $<$ 中期となり, 前期と中期の変化量が大き いように思われる。すすなわち, 前期では, 化学肥料区に比 べて有機堆肥区は有意に低かったものの, 後期では, 両区 間に有意差がなくなり, 連用開始後一定の年次が経過する と処理間の差が小さくなることを示していると思われる。 また, 籾殼堆肥区の中 5 年間以降には, 増収傾向 $(\mathrm{P}=0.130)$ が見られた，それに対して，化学肥料区の 5 年間の平均は, 前期，中期および後期いずれもかなり安定していて大きな 増減が見られなかったことから, 有機栽培の籾殼堆肥区で は, 連用を開始してから 6 年目以降に, 牛贅堆肥区では 5 年目以降に収量の向上が認められ, 中 5 年間の平均収量は 高まり, その後の後 5 年間も中 5 年間の収量レベルが持続 していると推察された。

堆肥の連用とは反対に, 無施用を継続した無肥料区は, 転換 4 年目までは $400 \mathrm{~g} \mathrm{~m}^{-2}$ 前後の比較的高い収量を維持し ていた（第 4 図）が， 5 年目以降急激に低下し， $330 \mathrm{~g} \mathrm{~m}^{-2}$ 前後で横ばい状態となったことから, 本水田の収量ポテン シャルはこの程度であることが示唆された。これらのこと から, 有機物の連用効果の発現には 5 年を要し, その逆に 水田の地力の蓄積は, 4 年間で消失すると推察された.

前田（2001）は, 牛霬, 落葉, 籾殼, 稲䔔, 麦禀を使っ た完熟堆肥を最初の 4 年間は $400 \mathrm{~kg} \mathrm{10a}^{-1}$, 後の 6 年間は $200 \mathrm{~kg} 10 \mathrm{a}^{-1} 10$ 年間連用したコシヒカリ低農薬栽培におい

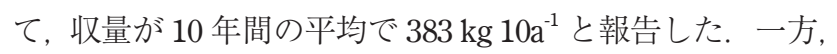
齊藤ら（2001）は，基肥に $1389 \mathrm{~g} \mathrm{~m}^{-2}$ の完熟堆厩肥と $106 \mathrm{~g}$ $\mathrm{m}^{-2}$ の発酵䳕霬, 追肥に $113 \mathrm{~g} \mathrm{~m}^{-2}$ の油粕を用いた有機栽培 の 10 年間の平均収量が $459 \mathrm{~g} \mathrm{~m}^{-2}$ であったと報告した。本 研究では, 連用効果が安定した 6 年目以降の 10 年間の平 
第 5 表 コメのアミロース含有率の推移.

\begin{tabular}{lccccc}
\hline & $\begin{array}{c}\text { 籾殼堆肥区 } \\
(\%)\end{array}$ & $\begin{array}{c}\text { 牛粪堆肥区 } \\
(\%)\end{array}$ & $\begin{array}{c}\text { 化学肥料区 } \\
(\%)\end{array}$ & $\begin{array}{c}\text { 無肥料区 } \\
(\%)\end{array}$ \\
\hline 1996 2000 年（前 5 年間) & $20.1 \pm 0.5$ & $20.1 \pm 0.5$ & $20.2 \pm 0.5$ & $20.0 \pm 0.9$ & n.s \\
$2001 \sim 2005$ 年（中 5 年間） & $19.7 \pm 0.9$ & $19.9 \pm 0.7$ & $19.9 \pm 1.0$ & $20.1 \pm 1.0$ & n.s \\
$2006 \sim 2010$ 年 (後 5 年間) & $19.2 \pm 0.5$ & $19.1 \pm 0.5$ & $19.4 \pm 0.5$ & $19.3 \pm 0.7$ & n.s \\
\hline
\end{tabular}

平均 \pm 標準偏差. 無肥料区は, 1998 年からの 13 年間の平均を示す.

n.s. は有意差がないことを示す.

第 6 表 コメの食味スコア值の推移

\begin{tabular}{|c|c|c|c|c|c|c|}
\hline 期 & 間 & $\begin{array}{c}\text { 籾殼堆肥区 } \\
\text { (点) }\end{array}$ & $\begin{array}{c}\text { 牛糞堆肥区 } \\
\text { (点) }\end{array}$ & $\begin{array}{c}\text { 化学肥料区 } \\
\text { (点) }\end{array}$ & $\begin{array}{c}\text { 無肥料区 } \\
\text { (点) }\end{array}$ & \\
\hline $1996 \sim 2000$ 年 & （前 5 年間） & $77 \pm 8$ & $79 \pm 6$ & $71 \pm 7$ & $84 \pm 4$ & n.s \\
\hline $2001 \sim 2005$ 年 & （中 5 年間） & $79 \pm 2$ & $78 \pm 5$ & $73 \pm 4$ & $80 \pm 3$ & n.s \\
\hline $2006 \sim 2010$ 年 & （後 5 年間） & $73 \pm 6$ & $75 \pm 6$ & $71 \pm 6$ & $73 \pm 7$ & n.s \\
\hline
\end{tabular}

平均 \pm 標準偏差. 無肥料区は, 1998 年からの 13 年間の平均を示す.

n.s. は有意差がないことを示す。

第 7 表 土壤養分の推移.

\begin{tabular}{|c|c|c|c|c|c|}
\hline & & 籾殼堆肥区 & 牛糞堆肥区 & 化学肥料区 & 無肥料区 \\
\hline \multirow{4}{*}{$\begin{array}{l}\text { 全窒素 } \\
\text { (\%) }\end{array}$} & 3 年目 & 0.33 & 0.24 & 0.21 & 0.23 \\
\hline & 11 年目 & 0.25 & 0.27 & 0.21 & 0.22 \\
\hline & 15 年目 & 0.29 & 0.29 & 0.22 & 0.22 \\
\hline & 18 年目 & 0.30 & 0.34 & 0.22 & 0.23 \\
\hline \multirow{4}{*}{$\begin{array}{c}\text { 有効態リン酸 } \\
(\mathrm{mg} / 100 \mathrm{~g})\end{array}$} & 3 年目 & 23.3 & 13.2 & 14.4 & 14.5 \\
\hline & 11 年目 & 10.0 & 9.3 & 21.1 & 10.5 \\
\hline & 15 年目 & 8.3 & 9.3 & 28.1 & 9.9 \\
\hline & 18 年目 & 7.7 & 10.1 & 27.5 & 9.8 \\
\hline \multirow{4}{*}{$\begin{array}{l}\text { 交換性加里 } \\
(\mathrm{mg} / 100 \mathrm{~g})\end{array}$} & 3 年目 & 35.7 & 40.6 & 24.0 & 20.3 \\
\hline & 11 年目 & 13.6 & 16.6 & 16.2 & 13.4 \\
\hline & 15 年目 & 13.2 & 16.9 & 15.8 & 11.4 \\
\hline & 18 年目 & 14.0 & 17.6 & 16.0 & 13.5 \\
\hline \multirow{4}{*}{$\begin{array}{l}\text { 交換性苦土 } \\
(\mathrm{mg} / 100 \mathrm{~g})\end{array}$} & 3 年目 & 68.0 & 85.1 & 78.2 & 72.1 \\
\hline & 11 年目 & 60.1 & 66.6 & 74.4 & 64.1 \\
\hline & 15 年目 & 61.3 & 64.1 & 80.4 & 61.7 \\
\hline & 18 年目 & 63.1 & 70.9 & 87.8 & 64.4 \\
\hline \multirow{4}{*}{$\begin{array}{l}\text { 交換性石灰 } \\
(\mathrm{mg} / 100 \mathrm{~g})\end{array}$} & 3 年目 & 268.8 & 328.3 & 292.1 & 288.3 \\
\hline & 11 年目 & 257.4 & 300.7 & 385.9 & 309.0 \\
\hline & 15 年目 & 288.3 & 309.2 & 424.6 & 314.5 \\
\hline & 18 年目 & 267.5 & 298.4 & 361.4 & 281.6 \\
\hline
\end{tabular}

均収量が, 籾殼堆肥区が $442 \mathrm{~g} \mathrm{~m}^{-2}$, 牛粪堆肥区が $450 \mathrm{~g} \mathrm{~m}^{-2}$ となり, 前田（2001）より高く, 齊藤ら（2001）と遜色の 無い平均収量であった。このことから, 有機栽培の収量レ ベルは $450 \mathrm{~g} \mathrm{~m}^{-2}$ 前後と推察した.

\section{5. 食味分析}

第 4 表，第 5 表，第 6 表に精玄米の食味分析の比較を示
した，前，中の各 5 年間は，それぞれ同じ分析機器を用い て分析したデータであることから，いずれのタンパク質含 有率抢よび食味のスコア值に打いても有意差はないもの の，化学肥料区に比べて有機栽培区はいずれもタンパク質 含有率はやや低く，食味のスコア值はやや高い傾向が見ら れた。しかし，有機栽培区で連用を継続することで，化学 肥料区との食味のスコアの差が, 大きくなることはなかっ 
た．アミロース含有率は，いずれの 5 年間においても処理 区間に殆ど差がみられなかった。研究開始後の当初 10 年 間と後の 5 年間では, 用いた食味計が異なったために, 後 の 5 年間では化学肥料区と有機栽培区の差は小さくなった ものの, 前, 中の各 5 年間と傾向は同じであった，近藤ら （1987）は, 堆肥・無農薬栽培米は慣行栽培米よりも精米 中のタンパク質含有率が減少したと報告し，王ら（1998） も精白米の全窒素含量が有機栽培に比較して慣行栽培で高 くなったと報告している. 本試験においても, 有機栽培区 は化学肥料栽培区と比較してタンパク含量が低いことが認 められた。玉置ら（1995），王ら（1998）は，アミロース 含量は品種固有の特性であり, 栽培方法によって大きな影 響を受けない形質であることを示唆している，本試験にお いても，いずれの栽培区もアミロース含有率に相違はみら れなかった。

\section{6. 土壤分析}

第 7 表に, 1998 年 (3 年目), 2006 年 (11 年目), 2010 年 $(15$ 年目), 2013 年 (18 年目) の土壌分析の結果を示し た，全窒素は，有機栽培区の牛糞堆肥区で漸増し，18 年 目には化学肥料区と無肥料区の 1.5 倍であった。一方, 堆 肥を投入しない化学肥料区と無肥料区は，変化が見られな かった. 有効態リン酸は, 籾殼堆肥区で漸減した。牛筫堆 肥区と無肥料区は, 11 年目以降大きな増減はなかった。一 方, 化学肥料区は 18 年目には他の 3 区の 3 倍量まで増加 した，交換性加里は，11年目以降全ての区に扮いて，大 きな増減はなかった。 交換性苦土は, 11 年目以降籾殼堆 肥区, 牛粪堆肥区および無肥料区で大きな増減はなかった。 化学肥料区は漸増傾向で, 他の 3 区より高かった，交換性 石灰は，増減は小さかった。

長期連用により増加したのは, 有機栽培区の全窒素で あった。このことは, 大場ら（2000）の結果と一致した。 有効態リン酸と交換性苦土は, 化学肥料区で増加した。有 効態リン酸は, 化学肥料区が有機栽培区の $2 \sim 3$ 倍の含量 であった. 籾款堆肥区の有効態リン酸は, 減少した。交換 性石灰は, 化学肥料区の含量が有機栽培区より高かった. 交換性生石灰の籾殼堆肥区と牛糞堆肥区の比較では, 牛糞 堆肥区が籾殼堆肥区より高い傾向がみられた。
謝辞：自然農法実践家中嶋恒雄氏には 10 年間籾喨堆肥 を提供して頂いた，記して感謝の意を表します。また，元 静岡大学農学部附属農場技官青木包雄氏に栽培管理ならび に技術補助を頂いた。ここに深く感謝の意を表します。

\section{引用文献}

浅井辰夫 ·平野清 · 前田節子 · 飛奈宏幸 - 西川浩二 2013. 緑肥レン ゲ (Astragalus sinicus L.) を 17 年間連用した水稲収量とその变動 要因. 日作紀 82: 353-359.

北海道立中央農業試験場・北海道農政部農業改良課 1992. 土䁃求よ び作物栄養の診断基準 - 分析法 (改訂版). 1-199.

上村幸廣 ·宇田川義夫 ·松原弘一郎 - 井ノ子昭夫 1983. 有機物施用 によるシラス水田土壌の生産力増強. 土肥誌 54: 131-136.

神谷径明 - 大石達明 · 嶋田昭史 - 水本順敏 - 堀兼明 1994. 中粗粒灰 色低地土水田における有機物及び珪カルの連用が土壤及び水稲に 与える影響. 静岡農試研報 38: 1-10.

片野学 1990. 自然農法のイネつくりー生育のすがたと栽培の実際. 農 文協, 東京. 1-246.

近藤栄昭 · 佐藤徳雄 · 芳賀文子 - 小峰洋美 · 鍬野信子 1987. 堆肥 · 無農薬と慣行法で栽培した米の食味の比較. 調理科学 20: 156-158. 前田忠信 2001. 堆肥連年施用水田と化学肥料連年施用水田に打ける 低農薬栽培した水稲収量の年次変動とその要因. 日作紀 70: 525529.

大場伸一. 卯月恒安. 高橋玲子. 原田直樹 2000. 水稲無農薬 - 無化 学肥料栽培の収量性. 東北農業研究 53: 69-70.

岡田茂吉 1953. 自然農法解説. 栄光社, 熱海. 1-236.

齋藤邦行 ·黑田俊郎・熊野誠一 2001. 水稲の有機栽培に関する継続 試験 -10 年間の生育収量 - . 日作紀 70: 530-540.

酒井憲一・山本富三 1999. 家畜ふん堆肥の窒素無機化予測および被 覆肥料の利用による水稲施肥量の削減と環境負荷低減. 土肥誌 70 : 185-189.

鈴木雅光 ·長谷川愿 ·宮野斉 · 大場伸一 1994. 水稲の無農薬 - 無化 学肥料栽培の基本指標. 山形農試研報 28: 39-56.

玉置雅彦・吉松敬祐 ·堀野俊郎 1995. 水稲有機栽農法実施年数と米 のアミログラム特性值およびミネラル含量との関係. 日作紀 64: 677-681.

玉置雅彦・猪谷富雄・山本由德 1999. 異なる光条件下における有機 質肥料と無機質肥料が水稲の生育に及ぼす影響. 日作紀 68: 16-20.

玉置雅彦・猪谷富雄 ·中野尚夫 2002 . 有機農法継続年巣が異なる水 稲の生育と収量 - 山口県下での一事例 - . 日作紀 71: 439-445.

王桂云・阿部利德・笹原健夫 1998. 慣行および有機栽培法で栽培し た水稲白米の全窒素・アミロース含量およびアミノ酸含量・組成. 日作紀 67: 307-311. 
Growth Characteristics, Yield and Eating Quality of Paddy Rice in Different Organic Cultivation Continued Fifteen Years : Tatsuo Asai ${ }^{1)}$, Hiroyuki Tobina ${ }^{1)}$, Setsuko MaEda ${ }^{2)}$ and Kouji Nishikawa ${ }^{1)}\left({ }^{1)}\right.$ Cent. for Edu. and Res. of Field Sci., Fac. of Agr., Shizuoka Univ., Fujieda 426-0001, Japan; ${ }^{2}$ Shizuoka Eiwa Gakuin Univ. Juni. Coll.)

Abstract : The effects of compost fertilization and pesticide application on the grain yield of an early maturing rice variety were examined for 15 years in the paddy field of Shizuoka University. Husk manure was applied without a pesticide (weeds were removed with a weeder and by hand) in the HMP-F plot from 1996 to 2010. Cattle manure was applied without a pesticide in the CMP-F plot from 1996 to 2010. Both chemical fertilizer and pesticide were applied in the CFP plot from 1996 to 2010. Neither fertilizer nor pesticide was applied in the NFP plot from 1998 to 2010. The rice grain yield during the first five years was 437, 430, 523 and $329 \mathrm{~g} \mathrm{~m}^{-2}$ respectively in the HMP-F, CMP-F, CFP and NFP plots. The effect of long-term manuring became apparent in CMP-F after the fifth year, and in HMP-F after the seventh year. It was confirmed that the eating quality value measured with a rice analyzer for eating quality tended to be high in the organic cultivation with husk manure or cattle manure compared with the conventional cultivation with a chemical fertilizer. It was clear that the total amount of nitrogen in paddy soil in the organic cultivation is larger than in conventional cultivation with a chemical fertilizer.

Key words : Cattle manure, Eating quality, Effect of long-term manuring, 15 successive years, Husk manure, Non-fertilizing cultivation, Paddy rice, Soil analysis. 